\title{
Potential uses of Elodea nuttallii-harvested biomass
}

\author{
Marcela Muñoz Escobar ${ }^{* *}$, Maryna Voyevoda ${ }^{2}$, Christoph Fühner ${ }^{1}$ and Andreas Zehnsdorf ${ }^{1}$
}

\begin{abstract}
Elodea nuttallii (PLANCH) St. John, an aquatic plant native to North America, shows invasive traits outside of its area of origin. In Europe, the plant has spread rapidly in water bodies. In Germany, the massive occurrence of E. nuttallii restricts recreational activities on lakes. Massive occurrences of E. nuttallii have been managed up to now by harvesting the plant and disposing of the biomass as organic waste, which results in high maintenance costs for lake administrators. Alternative uses to the disposal of the biomass were investigated. Analyzing the components and elemental composition of E. nuttallii samples from nine lakes in Germany, several potential uses were identified, such as the use of E. nuttallii biomass as a co-substrate with maize silage for biogas generation. Other potential applications, such as biochart production, soil amelioration, and energy recovery of feedstock chars in combustion plants, were identified from a hydrothermal carbonization process. The presence of $\beta$-sitosterol in $E$. nuttallii, which is used in the treatment of enlarged prostates, indicates a pharmaceutical use. Even though the elemental composition of $E$. nuttallii biomass contains the elements of a complete fertilizer, this particular use is not recommended given its slow decomposition in soil. The most feasible alternative identified was the use of $E$. nuttallii biomass as a co-substrate for biogas generation in combination with maize silage. The mixing of E. nuttallii with maize silage to facilitate storage and short distances between biogas plants and lakes with massive occurrence of E. nuttallii are important factors for its applicability.
\end{abstract}

Keywords: Elodea nuttallii, harvested biomass, potential uses

\section{Background}

Elodea nuttallii (PLANCH) St. John is a fresh water aquatic plant native to temperate North America [1], which grows in lakes, ponds, canals, and slow-moving waters $[2,3]$. In the past, often confused with the wellknown invasive water weed Elodea canadensis, E. nuttallii shows invasive traits where it has been introduced outside of its native area: rapid propagation and vegetative reproduction through fragments transported by water flows [2,4]. Its rapid propagation has even resulted in the displacement of E. canadensis [3,4]. According to Thiébaut [5], the introduction of non-native plants can lead to severe biological invasions; this description appears to apply to the spread of $E$. nuttallii.

Introduced into Europe in the first half of the twentieth century, E. nuttallii has been gaining attention due to its rapid spreading in European water bodies. $E$.

\footnotetext{
* Correspondence: marcela.munoz-escobar@ufz.de

${ }^{1}$ Centre for Environmental Biotechnology (UBZ), Leipzig, Germany

Full list of author information is available at the end of the article
}

nuttallii was first reported in the Netherlands in 1941 [6], in France in the early 1950s [3], in Britain in 1966, and in Austria in 1977 [2]. Currently, it appears that $E$. nuttallii is actively spreading in many parts of Europe [3]. In Germany, the plant was first reported in 1953 in the Münster Botanical Garden of the Federal State of North Rhine-Westphalia [6]. Initially predominant in western Germany, the plant has now spread almost all over the country [7].

The federal states mostly affected by the massive occurrence of E. nuttallii are (see Figure 1): North RhineWestphalia (lakes: Hengstey, Harkort, Kemnader, Eyller, Kranenburger, Ville, Rees, Windheim, Wolfssee, Diersfelder Waldsee, Unterbacher, and Toeppersee; dams: Neyetal and Lister dams), Lower Saxony (Steinhuder Meer lake) [8], and Saxony-Anhalt (Goitzsche lake) [9].

Apart from the negative impact on water quality as a consequence of the release of nutrients in a short period of time during autumn when the plants decay [10], the massive biomass produced by $E$. nuttallii also restricts 


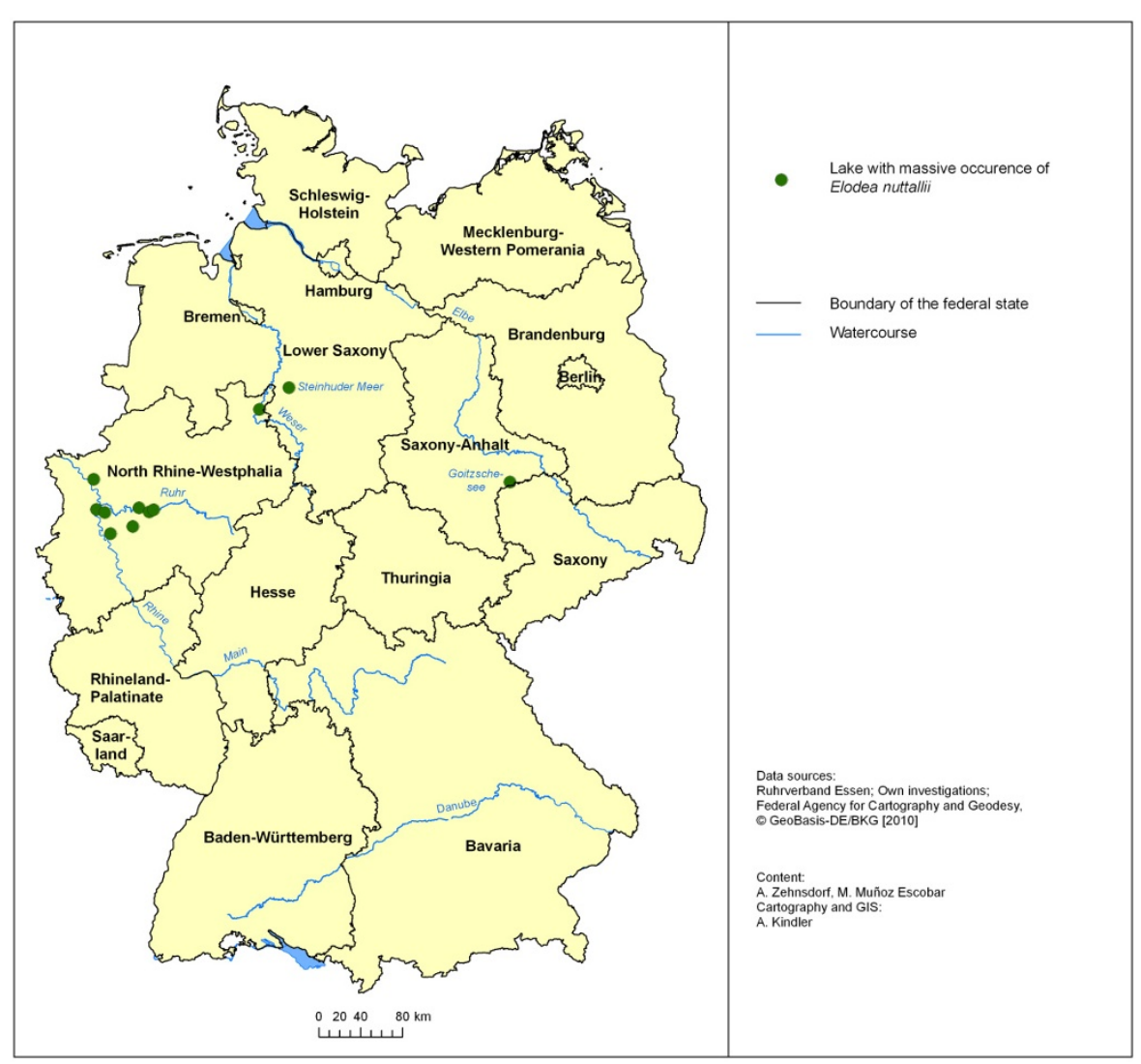

Figure 1 Federal states in Germany with massive occurrence of E. nuttallii until 2010.

water uses. Recreational activities on lakes are particularly affected by a massive occurrence of $E$. nuttallii; e.g., sailing, swimming, and surfing become either highly restricted or impossible $[7,8]$.

There are several options for controlling overabundant aquatic plants; among them are biological and chemical control as well as manual and mechanical harvesting [3]. In Germany, mechanical harvesting is the option applied since the other alternatives are either forbidden (chemical control) or are not effective enough to control the massive occurrence of $E$. nuttallii.

The mechanical harvesting of E. nuttallii is a costintensive measure [7]. In addition to the harvesting costs, the administrators of the lakes have to pay for the disposal of $E$. nuttallii biomass, which is classified as an organic waste in Germany.

Research exploring alternatives to the disposal of the biomass as an organic waste which treats the biomass as a raw material for other uses could offer an insight into more sustainable strategies for maintaining lakes in good condition and ensuring their use for recreational activities at lower maintenance costs for the lake administrators.

Alternatives to the disposal of the biomass could be established investigating the various components of $E$. nuttallii. In this paper, the results of research on the potential uses of $E$. nuttallii biomass as a co-substrate for the generation of biogas, for soil amendment after hydrothermal carbonization (HTC), for pharmaceutical extracts, and as a fertilizer are described.

\section{Materials and methods \\ Samples}

Fresh E. nuttallii biomass samples were collected from the following lakes in Germany: In North Rhine-Westphalia: Henne Dam (near Meschede) and Sorpe Dam (near Arnsberg) both located in the Homert Natural Park; Hengstey Lake (near Hagen), Kemnad Lake (near Bochum), Baldeney Lake (near Essen), Toepper Lake (near Duisburg). In Hesse: Perf Dam (near Marburg). In Lower Saxony: Lord lake (near Ankum). In SaxonyAnhalt: Goitzsche Lake (near Bitterfeld).

\section{Methods and instrumentation}

Determination of biogas formation and methane yield of $E$. nuttallii samples

Samples of E. nuttallii from five lakes (Henne Dam, Baldeney Lake, Toepper Lake, Lord Lake, and Goitzsche Lake) were anaerobically digested in the laboratory 
under static conditions using eudiometers. Anaerobic inoculum (250 g) were added to portions of plant material corresponding to $1 \mathrm{~g}$ of volatile solids and incubated in $500-\mathrm{mL}$ glass bottles at $39^{\circ} \mathrm{C}$ for 40 days. The inoculum originated from the anaerobic stabilization of excess sludge from municipal sewage treatment, which had been pre-treated under anaerobic conditions for 3 weeks. An inoculum without E. nuttallii was incubated as a negative control. The positive controls contained 1 g of micro-crystalline cellulose. All tests except the $E$. nuttallii samples from Lake Lord were run in triplicates.

Moreover, in a pilot biogas reactor with a working volume of $40 \mathrm{~L}$, maize silage was replaced step by step with Elodea of the harvested moisture content. The substituted amount of maize silage depended on the organic content and the oDM (i.e., the organic dry matter) of Elodea.

\section{Hydrothermal carbonization}

Hydrothermal carbonization (HTC) was carried out in a high-pressure laboratory autoclave (a 200-mL Model II from Carl Roth GmbH + Co KG, Karlsruhe, Germany). Air-dry Elodea was suspended with a mass ratio of $1: 10$ in a $0.01 \%(w / w)$ aqueous solution of citric acid and kept in the autoclave for $16 \mathrm{~h}$ at either $200^{\circ} \mathrm{C}$ or $240^{\circ} \mathrm{C}$ under autogenous pressures. After autoclaving, the suspensions were passed through 0.45 $\mu \mathrm{m}$ cellulose acetate filters. Filter residues were dried at $105^{\circ} \mathrm{C}$ and weighted.

\section{Determination of organic substances in plant samples}

For the extraction procedure, $4 \mathrm{~g}$ of homogenized dry plant material was extracted by pressurized liquid extraction using an "ASE200" instrument (Dionex, Sunnyvale, CA, USA). The sample was filled into a $16 \times 77$ $\mathrm{mm}$ extraction thimble (Schleicher and Schuell, Dassel, Germany) and transferred into an 11-mL stainless steel extraction cell. Cyclohexane and acetone at a ratio of 30:70 $(v / v)$ were used as extraction solvents. A pressure of $10 \mathrm{MPa}$ was applied for the static extraction at a temperature of $140^{\circ} \mathrm{C}$ for $15 \mathrm{~min}$ ( 2 cycles). The flush volume amounted to $50 \%$ of the extraction cell volume. The volumes of the resulting extracts were combined and evaporated to about $1 \mathrm{~mL}$. Clean-up on alumina using cyclohexane as an eluent removed parts of the dark green matrix and, after evaporating to $1 \mathrm{~mL}$, an aliquot of $1 \mu \mathrm{L}$ was used for the gas chromatography/mass spectroscopy (GC/MS) analysis.

GC/MS analysis was performed using a "TraceGCPolaris Q" GC-ion trap mass spectrometer system (Axel Semrau, Spockhövel, Germany) equipped with a split/ splitless injector. The temperature of the injector was set at $230^{\circ} \mathrm{C}$ and the temperature of the transfer line at $280^{\circ} \mathrm{C}$. The sample was injected in splitless mode using a splitless time of $1 \mathrm{~min}$. For GC separation, an HP $5 \mathrm{MS}$ capillary column $(30 \mathrm{~m}, 0.25 \mathrm{~mm}$ i.d., $0.25-\mu \mathrm{m}$ film) was applied using an oven heating program of: $60^{\circ}$ C, $1 \mathrm{~min} ; 15 \mathrm{grad} / \mathrm{min}$ to $280^{\circ} \mathrm{C}, 20 \mathrm{~min}$. Helium was used as a carrier gas under constant flow conditions (1 $\mathrm{mL} / \mathrm{min}$ ). The solvent delay time was set to $6 \mathrm{~min}$.

The mass spectrometer operated at electron impact ionization $(70 \mathrm{eV})$ in full scan mode (mass range 50 to 550 mass units) to identify the plant ingredients. Selected ion monitoring mode determining the target ions of sitosterol $(m / z 414,396,329$, and 213) was applied for the quantification of this component. The limit of quantification was found to be $500 \mathrm{ng} / \mathrm{mL}$ Elodea extract matrix $\pm 12 \%$ mean standard deviation.

$\beta$-Sitosterol was obtained from Supelco (Bellefonte, PA, USA). Cyclohexane and acetone (HPLC grade) were purchased from Supelco (Darmstadt, Germany). A solution of $\beta$-sitosterol in cyclohexane $(2 \mu \mathrm{g} / \mathrm{mL})$ was used to confirm the identification of $\beta$-sitosterol in the plant extracts.

\section{Determination of dry weight and volatile solids}

Fresh samples of E. nuttallii were weighed and dried at $105^{\circ} \mathrm{C}$ to determine the dry weight. The dried samples were treated at $550^{\circ} \mathrm{C}$ in a muffle furnace to determine the content of volatile solids.

\section{Determination of $C, H, N$, and $O$ in sediment, plant samples, and solid HTC products}

The dried materials were incinerated in a pure oxygen atmosphere at $950^{\circ} \mathrm{C}$ using a TruSpec CHN elemental analyzer (LECO Corporation, St Joseph, MI, USA). The carbon-containing components were quantified by IR analysis. The nitrogen-containing components were reduced to nitrogen and were quantified with a thermal conductivity detector. Oxygen concentrations were calculated as the difference between the overall biomass. The results of the $\mathrm{C} / \mathrm{H} / \mathrm{N}$-analyses and the elemental analyses are presented below.

\section{Determination of $P$ in plant samples and solid HTC products}

The analysis of the phosphorus content in particulate matter was carried out as reported earlier [11]. Total phosphorus in the Elodea biomass and HTC materials was measured according to the German standard methods (DIN 38414). Solid-phase phosphorus was determined after oxidation by ammonium nitrate in a muffle furnace. Portions of 0.1 to $0.3 \mathrm{~g}$ of the annealed residue were mixed with $25 \mathrm{~mL}$ of $1 \mathrm{M} \mathrm{HCl}$ and heated for 15 min. After cooling, deionized water was added to the suspension. After the addition of p-nitrophenol to an aliquot of the product, the solution was titrated with $\mathrm{NaOH}$ to yellow. The solution was discolored by the addition of sulfuric acid. $\mathrm{KMnO}_{4}$ solution and deionized water were added, resulting in a defined sample volume. The phosphorus concentration was determined photometrically by the addition of ascorbic acid and ammonium molybdate at $880 \mathrm{~nm}$. 


\section{Determination of metals in plant samples and solid HTC products}

The plant samples and solid HTC products were dried and ground. Portions of $0.45 \mathrm{~g}$ of the powder were mixed with $5 \mathrm{~mL}$ of $65 \% \mathrm{HNO}_{3}$ (suprapur, Merck, KGaA, Darmstadt, Germany) and $0.1 \mathrm{~mL}$ of $30 \% \mathrm{H}_{2} \mathrm{O}_{2}$ (suprapur, Merck). The mixtures were heated under pressure in an "UltraClave II" (MLS, Leutkirch, Germany) according to the following microwave oven program: $20^{\circ} \mathrm{C}$ to $200^{\circ} \mathrm{C}$ for $15 \mathrm{~min}, 200^{\circ} \mathrm{C}$ to $250^{\circ} \mathrm{C}$ for 10 min, $250^{\circ} \mathrm{C}$ hold for $15 \mathrm{~min}$, cool down. The products were diluted to a volume of $50 \mathrm{~mL}$ with deionized water (MilliQ-Element/Millipore). The resulting samples were analyzed by means of inductively coupled plasma mass spectrometry using an Elan DRC-e (Perkin Elmer Corp., Waltham, MA, USA) following a 1:10 dilution with $0.5 \%$ $(v / v) \mathrm{HNO}_{3}$ (ultrapur, Merck). The following isotopes were used for the measurements: $51-\mathrm{V}$; 52-Cr (using dynamic reaction cell (DRC) and methane as a reaction gas); 59-Co; 60-Ni; 75-As (using DRC with $\mathrm{O}_{2}$ as a reaction gas: measuring 91-(AsO+)); 85- Rb; 90-Zr; 118-Sn; and $\sum 206-, 207-$, and 208-Pb. The interferences of $\mathrm{Ca}$ on $60-\mathrm{Ni}$ and of $\mathrm{Cl}$ on $51-\mathrm{V}$ were corrected for using an equation. The interferences on 52-Cr and 75-As were taken into account by applying dynamic reaction cell technology. All measured concentrations were well above the limits of quantification.

\section{Results and discussion}

\section{E. nuttallii as a co-substrate for biogas plants}

The results of anaerobic digestion of E. nuttallii biomass from the five different lakes under static conditions in the laboratory showed a similar yield of biogas (see Table 1). These results demonstrate the independence of the biogas yield with respect to the site of biomass origin. With an average of 450 standard liters (SL)/ $\mathrm{kg}_{\mathrm{oDM}}$, the yield of biogas from E. nuttallii is within the average of biogas yields obtained from maize silage of $650 \mathrm{SL} / \mathrm{kg}_{\text {oDM }}$ [12], indicating a good potential for the use of the E. nuttallii biomass for biogas generation.

Nonetheless, the biogas generation related to fresh mass can be seen to be lower for $E$. nuttallii biomass (see Table 1), with $29 \mathrm{SL} / \mathrm{kg}_{\mathrm{FM}}$ compared to $200 \mathrm{SL} /$
$\mathrm{kg}_{\mathrm{FM}}$ of maize silage. The high content of water in $E$. nuttallii fresh biomass accounts for this lower value of biogas generation. While wilting the biomass straight after harvesting, up to $90 \%$ of the water content can be removed [13].

The digestion of E. nuttallii fresh mass as a single substrate in a laboratory reactor under continuous processing led to a reduction of more than $50 \%$ in the biogas yield. In order to test the potential of the use of $E$. nuttallii biomass as a co-substrate for biogas generation, additional experiments were carried out by gradually replacing maize silage with $E$. nuttallii biomass characterized by the harvested moisture content. The amount replaced was based on the organic dry matter values (oDM).

It was demonstrated that biogas generation with $100 \%$ E. nuttallii biomass is possible, though economically not viable. Figure 2 presents the results for the various mixtures, showing a decrease in the biogas yield when $E$. nuttallii biomass was added. One of the reasons for this decrease is the shorter residence time of E. nuttallii due to the lower organic dry matter content compared to maize silage, and the high content of water [13]. The mixture of $30 \%$ E. nuttallii biomass with $70 \%$ maize silage generated a biogas yield of $580 \mathrm{SL} / \mathrm{kg}_{\mathrm{oDM}}$, which remains within the range of biogas yields from maize silage.

Furthermore, an addition of trace elements for process stabilization is needed for the generation of biogas. The use of E. nuttallii biomass for biogas generation can offer additional benefits for the process due to the presence of trace elements.

In regards to the use of E. nuttallii biomass as a cosubstrate for biogas generation, one of the issues to be resolved is biomass storage. Biomass to be used for this purpose should be available for a long period of time. However, freshly harvested E. nuttallii biomass decomposes quickly and generates a strong putrid smell.

Zehnsdorf et al. [13] reported a good silage quality for a mixture of $30 \%$ pre-wilted E. nuttallii biomass and $70 \%$ maize, generating a biogas yield of $694 \mathrm{SL} / \mathrm{kg}_{\mathrm{oDM}}$ in laboratory experiments. At this mixture ratio with

Table 1 Analysis of E. nuttallii samples from five lakes in Germany $(n=3$ )

\begin{tabular}{|c|c|c|c|c|c|}
\hline & $\mathrm{DM}(\%$ in $\mathrm{FM})$ & oDM (\% in FM) & Gas formation(SL/kgoDM) & Gas formation(SL/ $\left.\mathrm{kg}_{\mathrm{FM}}\right)$ & $\mathrm{CH}_{4}(\%)$ \\
\hline Baldeney Lake Essen & 16.67 & 7.18 & 416 & 29.8 & 63 \\
\hline Goitzsche Lake Bitterfeld & 6.74 & 4.36 & 476 & 20.6 & 55 \\
\hline Hennetal Dam Meschede & 24.98 & 6.32 & 457 & 28.9 & 62 \\
\hline Lord Lake Osnabrück & 6.33 & 4.82 & 415 & 20.0 & 64 \\
\hline Toepper Lake Duisburg & 11.64 & 8.54 & 520 & 44.4 & 58 \\
\hline
\end{tabular}

$\mathrm{DM}$, dry matter; FM, in fresh mass; oCM, organic dry matter; $\mathrm{SL} / \mathrm{kg}_{\mathrm{oDM}}$, standard liters per kilogram of organic dry matter; $\mathrm{SL} / \mathrm{kg}_{\mathrm{FM}}$, standard liters per kilogram of fresh mass; $\mathrm{CH}_{4}$, methane. 


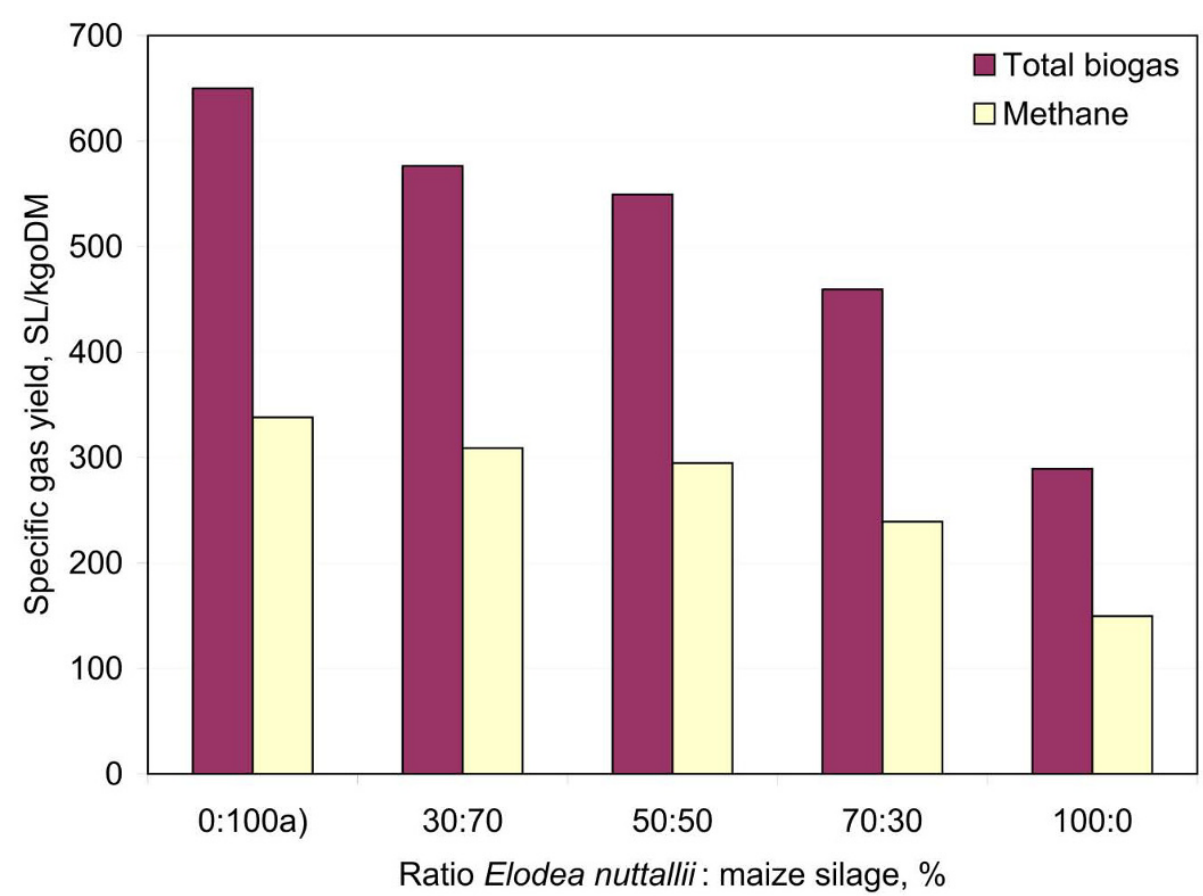

Figure 2 Specific gas yield from E. nuttallii-maize substrate mixtures. a), Döhler H (2009):222 [12].

maize, it is feasible to store E. nuttallii biomass that delivers a good performance in regards to biogas yield.

One condition for the feasibility of this alternative is a short distance between the locations of biomass harvesting and the biogas plants in order to avoid high transportation costs. In Germany, this condition is fulfilled since there are a large number of biogas plants close to the places of massive occurrences of E. nuttallii [7].

\section{Hydrothermal carbonization}

HTC is a process for the thermochemical conversion of carbonaceous materials in the presence of excess water at temperatures of $>180^{\circ} \mathrm{C}$ and autogenous pressures of $>1.0 \mathrm{MPa}$ for periods of several hours to days $[14,15]$. HTC and HTC-related processes with milder temperature/pressure regimes and shorter residence times can mainly be used for the carbonization and stabilization or the disintegration of water-rich biomass.

In the field of wastewater treatment, thermo-pressure technologies such as the CAMBI process (CAMBI, Asker, Norway) [16], are focused on increasing the dewaterability and digestibility of sewage sludges by cytolysis and the disruption of colloidal structures $[17,18]$. In addition, hydrothermal pretreatment can reduce foam formation in digestion processes [19]. Most studies on thermo-pressure-based methods for sewage sludge disintegration reported an optimal temperature range of $160^{\circ} \mathrm{C}$ to $180^{\circ} \mathrm{C}$ and treatment times of 30 to $60 \mathrm{~min}$ [18]. Exposure to higher temperatures can decrease the biodegradability of certain fractions of the feedstock due to the formation of refractory substances [20].

In contrast to the application of thermal hydrolysis for sewage sludge disintegration, the formation of recalcitrant products is one of the main goals when applying the more severe conditions of HTC. While mass yields often decrease, the relative carbon content of solid HTC products usually increases with the temperature and residence time of the conversion process [15,21]. Dehydration, decarboxylation, demethanation, and reactions of secondary polymerization that take place at temperatures $>170^{\circ} \mathrm{C}$ lead to the formation of lignite-like materials with decreased $\mathrm{O} / \mathrm{C}$ and $\mathrm{H} / \mathrm{C}$ ratios and increased heating values. The generation of polycondensed aromatic structures is assumed to be responsible for the recalcitrance of pyrolized materials to microbial degradation [22]. Similar substances are most probably also generated in the course of HTC.

Against this background, there exists an increasing interest in HTC with regard to the use of its solid conversion products for soil carbon sequestration and soil amelioration [15,23], on the one hand, or as a renewable fuel with an increased calorific value [15,22], on the other. Compared to pyrolysis-based systems, HTC strategies are expected to be energetically advantageous for wet and moist feedstocks, as they allow for char production without predrying and for concomitant improvements of the mechanical dewaterability of the biomass. 
Since the water-rich biomass of E. nuttallii does not face any relevant competition from alternative utilization routes, HTC with its multiple options for the integration into energy and material recovery systems appears to be particularly suitable for this material.

The first $16 \mathrm{~h}$-experiments in our study regarding the $\mathrm{HTC}$ of Elodea biomass at $200^{\circ} \mathrm{C}$ and $240^{\circ} \mathrm{C}$ resulted in $65 \%$ and $59.5 \%$ of solid conversion products on a weight basis (Table 2). These char yields are in the range of values given by other authors [21]. Tsukashi [24], for example, obtained mass yields of $66 \%$ and $56 \%$ for wood that was treated for $72 \mathrm{~h}$ at $200^{\circ} \mathrm{C}$ and $250^{\circ} \mathrm{C}$, respectively. At the same time, as the char yields of Elodea decreased, the concentrations of ash elements in the dry mass increased from $16.3 \%$ to $29.9 \%$ and $36.1 \%$. In terms of the potential use of HTC chars for soil amelioration, the allocation of plant nutrient elements to the solid, liquid, and gaseous HTC products is of particular interest. When the HTC temperature was increased, the amount of major plant nutrients in the char decreased to different extents (Table 2). While on average $85 \%$ of $\mathrm{K}$ and $69 \%$ of $\mathrm{N}$ were removed from the particulate fraction, only around $20 \%$ of $\mathrm{Mg}$ and $10 \%$ of $\mathrm{P}$ were dissolved in the process waters. Faced with the high concentration of dissolved plant nutrients, such as $\mathrm{K}$ and $\mathrm{N}$, future work has to develop strategies for an efficient treatment of process waters and recycling of nutrients in plant available speciations.

Elemental analyses showed an unexpectedly low C concentration in the Elodea biomass (Table 2). In addition, the tentative experiments in this study did not establish the relative accumulation of $\mathrm{C}$ and the decrease of the molar $\mathrm{O} / \mathrm{C}$ ratio that is usually caused by dehydration and decarboxylation reactions in HTC processes [21]. Thus, even if the $\mathrm{H} / \mathrm{C}$ values of the feedstock and their decline in the chars matched those obtained in other studies [21], the results of the $C$ and $\mathrm{H}$ analyses as well as the calculated values of the oxygen

Table 2 Mass yields and elemental composition of biomass and solid HTC products (HTC chars) of E. nuttallii

\begin{tabular}{|c|c|c|c|c|}
\hline & & HTC & HTC $200^{\circ} \mathrm{C} / 16 \mathrm{~h}$ & HTC $240^{\circ} \mathrm{C} / 16 \mathrm{~h}$ \\
\hline Mass yield & $(\% w / w)^{a}$ & - & 65.0 & 59.5 \\
\hline C & $(\% w / w)$ & 25.9 & 23.9 & 19.4 \\
\hline O & $(\% w / w)$ & 50.8 & 41.5 & 40.9 \\
\hline $\mathrm{H}$ & $(\% w / w)$ & 3.45 & 2.36 & 1.58 \\
\hline $\mathrm{N}$ & $(\% w / w)$ & 2.25 & 1.24 & 1.01 \\
\hline K & $(\% w / w)$ & 2.95 & 0.64 & 0.23 \\
\hline $\mathrm{Mg}$ & $(\% w / w)$ & 0.19 & 0.16 & 0.15 \\
\hline$P$ & $(\% w / w)$ & 0.17 & 0.16 & 0.14 \\
\hline $\mathrm{H} / \mathrm{C}$ & $(\mathrm{mol} / \mathrm{mol})$ & 1.60 & 1.19 & 0.98 \\
\hline $\mathrm{O} / \mathrm{C}$ & $(\mathrm{mol} / \mathrm{mol})$ & 1.47 & 1.31 & 1.58 \\
\hline
\end{tabular}

${ }^{a}$ Weight percent of dry matter. concentrations should have to be verified by more comprehensive work. In order to balance the suitability of hydrothermal processes for energy recovery of Elodea biomass and/or its recycling according to the biochar concept, detailed investigations of the conversion processes and their liquid and solid conversion products should be performed in the future.

\section{Potential use of $E$. nuttallii biomass for pharmaceutical extracts}

The medical use of $E$. nuttallii in its area of origin by indigenous cultures provides initial indications of the potential use of the plant for medical or cosmetic purposes. However, the results of a study of a large ethnic group settled around the Great Lakes of North America showed that unlike with $E$. canadensis and E. potamogeton, there are no references to the use of E. nuttallii (Schröder 2009, unpublished observations). According to Hegnauer [25], E. nuttallii does not contain any toxic or bitter components.

From the determination of organic substances in $E$. nuttallii in this research, it was established that there is a content of up to $462 \mathrm{ppm}$ of $\beta$-sitosterol in the plant. This substance is applied in the medical treatment of enlarged prostates and prostate hyperplasia [26-28].

The concentration of $\beta$-sitosterol in E. nuttallii is lower than that found in other plants such as sage (Salvia officinalis), 2,450 ppm in leaves, hawthorn (Crataegus laevigata), 5,100 to 6,200 ppm in leaves, and basil (Ocimum basilicum L.), 896 to 1,705 ppm in leaves [29]. The extraction of $\beta$-sitosterol from $E$. nuttallii would therefore appear not to offer good prospects.

\section{Potential use of $E$. nuttallii as a fertilizer}

The elemental composition drawn from dry matter of E. nuttallii showed a relative average composition of nitrogen $(\mathrm{N}) 2.8 \% \pm 0.7 \%$, phosphorous (P) $0.4 \% \pm$ $0.18 \%$, and potassium (K) $2.9 \% \pm 1.1 \%$. Moreover, other main elements were found in the following percentages: magnesium $(\mathrm{Mg}) 0.24 \% \pm 0.06 \%$, calcium (Ca) $5.3 \% \pm 3.1 \%$, iron $(\mathrm{Fe}) 0.37 \% \pm 0.21 \%$, and sulfur (S) $0.26 \% \pm 0.2 \%$. The trace elements cobalt (Co) 11 ppm, copper $(\mathrm{Cu}) 26 \mathrm{ppm}$, and zinc $(\mathrm{Zn}) 305 \mathrm{ppm}$ were also identified.

The composition of E. nuttallii biomass contains therefore the elements of a complete fertilizer (NPK) and other important elements for plant growth. The potential for using the biomass as an organic fertilizer is therefore confirmed from the point of view of the elemental composition. However, composting tests showed a slow degradation of the biomass in the soil, with decomposition taking years due to the high content of cellulose $[8,18,19]$. Further research regarding the cell structure of the plant is needed to identify potential 
uses derived from the content of cellulose in the biomass.

The rich elemental composition of E. nuttallii associated with its high capacity for nutrient uptake [30,31] can generate water quality problems due to the release of nutrients in autumn when the plants decay [10]. By periodically harvesting the plant, these nutrients are extracted from the water, thus controlling eutrophication and quality problems.

\section{Conclusions}

In this paper, several options for the use of E. nuttallii biomass as alternatives to the disposal as organic waste were reviewed. Investigating the substances and elemental composition of the plant allows users to determine its potential for biogas generation and pharmaceutical application. However, the use as an organic fertilizer is not recommended.

E. nuttallii biomass can be employed as a co-substrate for biogas generation. The biogas yield of the biomass based on the organic dry matter is within the range of biogas yields obtained from maize silage. The high water content of the harvested biomass and problems with storage can be solved by producing a silage with a mixture of $30 \%$ pre-wilted E. nuttallii biomass and $70 \%$ maize. This mixture has a higher biogas yield than $E$. nuttallii biomass alone. The use of E. nuttallii biomass could be beneficial for biogas production since it contains the trace elements needed for the stabilization of the process. Short distances are desirable as regards the transportation of biomass to biogas plants, which is the case in Germany. These results show that the potential use of E. nuttallii biomass as a co-substrate for biogas generation is one of the most feasible applications among those described in this paper. Further experiments on the practicality of this application of E. nuttallii biomass in real-scale biogas plants are needed.

HTC and hydrothermal technologies for biomass disintegration have the potential to deliver sustainable material and/or energy recovery of $E$. nuttallii biomass. In principle, the high water contents of hydrophytes fulfill the prerequisites for running these processes. Conceptually, the reactions taking place during HTC increase the metabolic recalcitrance and the calorific value of carbonaceous feedstocks. HTC strategies could therefore be suitable for both the use of $E$. nuttallii in biochar-related concepts of carbon sequestration and soil amelioration as well as for the energy recovery of the feedstock chars in combustion plants. Even under milder temperature/pressure conditions and at shorter treatment times than typical for HTC, the hydrothermal treatment is accompanied by the disintegration of biomass. The cytolysis and disruption of colloidal structures not only improves the digestability of the feedstock but also its dewaterability.
Thus, thermo-pressure pretreatment could also be a valuable tool for the use of Elodea in biogas plants. Though our work has not been able to demonstrate effective carbonization as yet, HTC would appear to be applicable for the conversion of Elodea biomass in principle. More detailed studies have to be performed on hydrothermal conversion technologies and the characteristics of their products to judge the applicability of the concepts presented here for the recovery of E. nuttallii in practice. In particular, HTC products and those of related technologies such as the CAMBI process for sewage sludge treatment have not been investigated sufficiently thus far with regard to their value for soil amelioration and carbon sequestration.

The determination of the concentration of $\beta$-sitosterol in E. nuttallii biomass demonstrates its potential application as a raw material for the extraction of this substance that is used for the medical treatment of hyperplasia. Although the concentration of $\beta$-sitosterol found in E. nuttallii is lower than that found in other plants, it is important to consider that, once harvested, E. nuttallii biomass is a raw material available without extra production costs - an aspect that might make it an attractive source of $\beta$-sitosterol.

Even though the elemental composition of E. nuttallii biomass contains the basic nutrients for a complete fertilizer as well as trace elements, the use of the biomass as an organic fertilizer is not to be recommended due to its slow decomposition in soil. Further research regarding potential applications derived from the high content of cellulose (responsible for the slow decomposition of the biomass in the soil) and the extraction of nutrients for the production of inorganic fertilizer is needed.

The feasibility of alternative applications of E. nuttallii biomass should be assessed for each particular case. Whether the biomass is to be disposed of as an organic waste or can be used for one of the alternatives presented in this paper is ultimately an economic decision.

\section{Acknowledgements}

The authors would like to thank the following people for their collaboration: From the Helmholtz Centre for Environmental Research - UFZ: Dr. Igor Baskyr from the Department of Enviromental Engineering for undertaking the experiments on Hydrothermal Carbonization; Michael Seirig from the Centre for Environmental Biotechnology for carrying out the experiments on the substititon of E. nuttallii and maize silage; Dr. Annegret Kindler from the Department of Urban and Environmental Sociology for the cartography work; Dr. Monika Möder from the Analytical Chemistry Department and the staff of the Analytic Chemistry Department for carrying out the laboratory analyses; and from the German Biomass Research Centre, DBZF, Dr. Jürgen Pröter for the experiments regarding the potential gas production with $E$. nuttallii biomass.

\section{Author details}

${ }^{1}$ Centre for Environmental Biotechnology (UBZ), Leipzig, Germany ${ }^{2}$ Analytical Chemistry Department at UFZ-Helmholtz Centre for Environmental Research, Permoser Strasse 15, 04318, Leipzig, Germany 


\section{Authors' contributions}

MME evaluated the potential for exploitation of E. nuttallii and drafted the manuscript. MV carried out the chemical analyses. CF investigated the possibility of the use of E. nuttallii for hydrothermal carbonization. AZ conducted the field studies and coordinated the investigations. All authors read and approved the final manuscript.

\section{Competing interests}

The authors declare that they have no competing interests.

Received: 2 September 2011 Accepted: 21 November 2011 Published: 21 November 2011

\section{References}

1. Barrat-Segretain MH (2001) Invasive species in the Rhone River floodplain (France): replacement of Elodea canadensis MICHAUX by E. nuttallii St. JOHN in two former river channels. Arch Hydrobiol 152:237-251

2. Cook CDK, Urmi-König K (1985) A revision of the genus Elodea (Hydrocharitaceae). Aquat Bot 21:111-156

3. Di Nino F, Thiébaut G, Muller S (2005) Response of E. nuttallii (PLANCH.) H. St. JOHN to manual harvesting in the North-East of France. Arch Hydrobiol 551:147-157

4. Barrat-Segretain MH (2005) Competition between invasive and indigenous species: impact of spatial pattern and development stage. Plant Ecol 180:153-160

5. Thiébaut G (2007) Invasion success of non-indigenous aquatic and semiaquatic plants in their native and introduced ranges. A comparison between their invasiveness in North America and in France. Biol Invasions 9:1-12

6. Weber-Oldecop DW (1977) St. JOHN, eine neue limnische Phanerogame der deutschen Flora. Arch Hydrobiol 79:397-403

7. Zehnsdorf A, Kindler A, Muñoz Escobar M (2011) Neophyten - Potenziale ihrer Nutzung. In: Pinnekamp J (ed) Proceedings of the 44th Essener Tagung für Wasser und Abfallwirtschaft. "Zukunftsfähige Wasserwirtschaft kosteneffizient und energiebewusst", Aachen. Institut für Siedlungswasserwirtschaft der Rhein.-Westf Techn Hochschule

8. Podraza $P$, Brinkmann T, Evers P, Felde D, Frost U, Klopp R, Knotte H, Kühlmann M, Kuk M, Lipka $P$, Nusch E, Stengert M, Wessel M, van der Weyer K (2008) Untersuchungen zur Massenentwicklung von Wasserpflanzen in den Ruhrstauseen und Gegenmaßnahmen. Abschlussbericht zum MUNLV-Forschungsvorhaben

9. Frank C (2006) Beobachtungen zur Einbürgerung neuer Arten in SachsenAnhalt Mitt Florist Kart Sachen-Anhalt. 11:81-90

10. van Donk E, Gulati RD, ledema A, Meulemans JT (1993) Macrophyte-related shifts in the nitrogen and phosphorus contents of the different trophic levels in a biomanipulated shallow lake. Arch Hydrobiol 251:19-26

11. Rönicke $H$, Dörffer $R$, Siewers $H$, Büttner $O$, Lindenschmidt KE, Herzsprung $P$, Beyer M, Rupp H (2008) Phosphorus input by Nordic geese to the euthrophic Lake Arendesse, Germany. Arch Hydrobiol 172:111-119

12. Döhler H (2009) Faustzahlen Biogas. Kuratorium für Technik und Bauwesen in der Landwirtschaft. Darmstadt: Fachagentur Nachwachsende Rohstoffe, FNR

13. Zehnsdorf A, Korn U, Pröter J, Naumann D, Seirig M (2011) Western waterweed (Elodea nuttallii) as a co-substrate for biogas plant. Landtechnik 66:136-139

14. Titirici MM, Thomas A, Antonietti M (2007) Back in the black: hydrothermal carbonization of plant material as an efficient chemical process to treat the $\mathrm{CO}_{2}$ problem? New J Chem 31:787-789

15. Funke A, Ziegler $F$ (2009) Hydrothermal carbonization of biomass: a literature survey focussing on its technical implementation and prospects. Proceedings of the 17th European Biomass Conference and Exhibition, Hamburg June 2009. Italy: ETA-Renewable Energies

16. Kepp U, Machenbach I, Weisz N, Solheim OE (2000) Enhanced stabilization of sewage sludge through thermo hydrolysis - three years of experience with full scale plant. Water Sc Technol 42:89-96

17. Neyens E, Baeyens J (2003) A review of thermal sludge pre-treatment processes to improve dewaterability. J Hazard Mater 98:51-67

18. Carrere H, Dumas C, Battimelli A, Batstone DJ, Delgenes JP, Steyer JP, Ferrer I (2010) Pretreatment methods to improve sludge anaerobic degradability: a review. J Hazard Mater 183:1-15
19. Jolis D, Marneri M (2006) Thermal hydrolysis of secondary scum for control of biological foam. Water Environ Res 78:835-841

20. Bougrier C, Delgenes JP, Carrere H (2007) Impacts of thermal pretreatments on the semi-continuous anaerobic digestion of waste activated sludge. Biochem Eng J 34:20-27

21. Funke A, Ziegler $F(2010)$ Hydrothermal carbonization of biomass: a summary and discussion of chemical mechanisms for process engineering. Biofuels Bioprod Bioref 4:160-177

22. Glaser B (2007) Prehistorically modified soils of central Amazonia: a model for sustainable agriculture in the twenty-first century. Philos Trans R Soc, B 362:187-196

23. Libra J, Ro K, Kammann C, Funke A, Berge ND, Neubauer Y, Titirici M, Fühner C, Bens O, Kern J, Emmerich KH (2011) Hydrothermal carbonization of biomass residuals: a comparative review of the chemistry, processes and applications of wet and dry pyrolysis. Biofuels 2:71-106

24. Tsukashi H (1966) Infrared spectra of artificial coal made from submerged wood at Uozu Toyama Prefecture Japan. Bull Chem Soc Jpn 39:460-465

25. Hegnauer R (1963) Chemotaxonomie der Pflanzen: eine Übersicht über die Verbreitung und die systematische Bedeutung der Pflanzenstoffe. Basel: Birkhäuser

26. von Holtz RL, Fink CS, Awad AB (1998) B-Sitosterol activates the sphingomyelin cycle and induces apoptosis in LNCaP human prostate cancer cells. Nutr Cancer 32:8-12

27. Berges RR, Kassen A, Senge $T$ (2000) Treatment of symptomatic benign prostatic hyperplasia with $\beta$-sitosterol: an 18-month follow-up. BJU Int 85:842-846

28. Awad AB, Fink CS, Williams $H$, Kim U (2001) In vitro and in vivo (SCID mice) effects of phytosterols on the growth and dissemination of human prostate cancer PC-3 cells. Eur J Cancer Prev 10:507-513

29. Beckstrom-Sternberg SM, Duke JA Plants containing sisterol. In: Phytochemical and ethnobotanical databases. Agricultural Research Service. United States Department of Agriculturehttp://sun.ars-grin.gov

30. Ozimek T, van Donk E, Gulati RD (1993) Growth and nutrient uptake by two species of Elodea in experiment conditions and their role in nutrient accumulation in a macrophyte dominated lake. Arch Hydrobiol 251:13-18

31. Garbey C, Murphy K, Thiébaut G, Muller S (2004) Variation in P-content in aquatic plant tissues offers an efficient tool for determining plant growth strategies along a resource gradient. Freshw Biol 49:346-356

doi:10.1186/2192-0567-1-4

Cite this article as: Muñoz Escobar et al: Potential uses of Elodea nuttallii-harvested biomass. Energy, Sustainability and Society 2011 1:4.

\section{Submit your manuscript to a SpringerOpen ${ }^{\circ}$ journal and benefit from:}

- Convenient online submission

- Rigorous peer review

- Immediate publication on acceptance

- Open access: articles freely available online

- High visibility within the field

- Retaining the copyright to your article

Submit your next manuscript at $>$ springeropen.com 